\title{
Populism, Protectionism and Paralysis
}

Populism, protectionism and paralysis have become key features of almost all Western democ-racies today. Right-wing and left-wing populism has contributed to an increasingly confrontational discourse. It also has had a major economic impact. The rise of protectionism and economic nationalism is one result of a populism that paints foreigners, immigrants, Europe or China as enemies of national interests. At the same time, populist politics that blame all ills on others while promising a brighter future make it hard to establish an honest and constructive debate about needed reforms in times when globalisation and technological change are fundamentally transforming societies and economies everywhere.

Tackling political populism requires understanding the root causes. While cultural factors may have contributed to its rise, it is widely established by now that economic factors also play a decisive role. ${ }^{2}$ One important economic dimension is that of the rising inequality in wealth, income, jobs, education and various dimensions of economic opportunity. Thus tackling populism ultimately requires addressing economic and social inequalities within as well as across countries.

In most European nations, populism has been directed not only against elites and other groups within nation states, but increasingly against Europe and its institutions. ${ }^{3}$ This is threatening the entire process of European integration, with the exit of the United Kingdom from the European Union on 31 January 2020 being but one example. One key feature in the Brexit debate has been the immigration of Europeans to the UK over the past 20 years and the desire to strengthen national sovereignty, for which European integration has been seen by many Britons as a major impediment. While one may disagree on whether Britain will really be able to strengthen national sovereignty - or whether in fact national sovereignty will decline further as many important interests of Britain in the past were protected by the EU in an increasingly competitive global environment against large political and economic players, in particular the United States and China - pro-Brexit voices have repeatedly blamed national failures, such as those related to the National Health Service, on Europe.

However, such anti-European populism has not only been present in Britain, but in every single European country. One example is the bashing of the European Central Bank (ECB) and the euro, in particular in Germany, for challenges or problems that are essentially outside of the sphere of influence of the ECB. Politicians and the media are blaming the ECB for stealing from the small German saver through low interest rates, for damaging German banks and for making Germany pay for the mistakes made by the other European countries and contribute to financial costs. The former German finance minister even blamed the ECB for the rise of the right-wing Alternative für Deutschland (AfD) party in Germany. While many Europeans have not fallen prey to such anti-European rhetoric, it has damaged the reputation of European institutions, thereby weakening the case for pursuing European reforms.

(C) The Author(s) 2020. Open Access: This article is distributed under the terms of the Creative Commons Attribution 4.0 International License (https://creativecommons.org/licenses/by/4.0/).

Open Access funding provided by ZBW - Leibniz Information Centre for Economics.

1 P. Norris, R. Inglehart: Cultural Backlash: Trump, Brexit, and Authoritarian Populism, Cambridge 2019, Cambridge University Press.

2 D. Rodrik: Many forms of populism, VoxEU.org, 29 October 2019; B. Eichengreen: The two faces of populism, VoxEU.org, 29 October 2019.

3 P. Collier: The Future of Capitalism: Facing the New Anxieties, London 2018, Penguin Random House; M. Fratzscher: The Germany Illusion: Between Economic Euphoria and Despair, New York 2018, Oxford University Press. 
Moreover, this anti-European populism and nationalism has given rise to economic protectionism. US President Donald Trump has openly been pursuing an 'America first' strategy, in which he has cancelled several multilateral or international treaties, such as the 2015 Paris Agreement on climate change, free trade agreements in North America and the Iran nuclear deal, to name but a few. In 2018 Trump openly threatened trade tariffs against China and European economies, in particular Germany and German automobiles. He engaged in a tax reform with the declared objective of bringing American capital back home.

To be fair, most European countries have also been ratcheting up protectionist economic policies in recent years. Taking Germany again as an example, its government has repeatedly denied that its huge current account surplus of 230 billion euro, or $7 \%$ of German GDP, constitutes a form of protectionism. Not only is this surplus in breach of European rules (specifically the macroeconomic imbalances procedure) and does it contribute to global imbalances in trade and capital flows, but it is directly the result of mercantilist policies, which encourage exports and discourage imports, e.g. by regulating services sectors in a way that makes it difficult for foreign companies to compete and by creating high barriers to raising investment with Germany.

The protectionism in Europe and elsewhere is not just linked to trade, but also to foreign direct investment, taxation, public procurement and the value of currencies. China triggered a controversy in the summer of 2019 by devaluing its currency, with many other Asian countries following suit, while the US and the euro area could not counter such policies. The discussion in many European countries to ban Chinese companies from investing in key infrastructure, such as telecommunications or high-tech industries, is seen by many as another form of protectionism.

In short, while one may argue about the specific place where justified market-oriented economic policies end and protectionism begins, there has been a clear and pervasive move towards nationalist and protectionist economic policies almost everywhere in the Western world in recent years. This includes not only reforms at the national level, but reforms of European institutions and policy in particular. For instance, much-needed reforms of the Economic and Monetary Union have stalled in recent years as national politicians have been highly suspicious of any changes that mean more competencies for Europe or even simply more coordination among national policies. This ranges from industrial and competition policies as well as climate and energy policies to reforms of social security systems.

How can anti-European populism be addressed and dealt with? The answer depends on the origins of such populism. While globalisation and technological change may have been an important driver behind economic inequality, economic and social reforms at the national level have done often little to address them. An example of this is the rise of the right-wing, populist AfD party in Germany, which can to a large extent be explained by increasing economic and social inequalities. A study by Franz et al. finds that citizens in regions with weak social and demographic structures, with few economic opportunities, low growth and high unemployment voted in much higher numbers for the AfD in the national elections in 2017 and the European elections in $2019 .{ }^{4}$ In fact, these factors explain up to $70 \%$ of the votes for the AfD in electoral districts. Hence economic and social polarisation has clearly played a role in the rise of populist parties and populist policies.

In conclusion, rising economic and social inequalities have been one important cause behind populism, protectionism and paralysis in Europe. Curtailing economic protectionism and overcoming the paralysis by improving economic inclusion and social safety nets, and by creating opportunities for more Europeans to find jobs and benefit from globalisation and technological change should be important first steps for European governments to reduce the scope for populist politicians and activists.

Marcel Fratzscher, German Institute for Economic Research (DIW), Berlin, Germany.
4 C. Franz, M. Fratzscher, A.S. Kritikos: At Opposite Poles: How the Success of the Green Party and AfD Reflects the Geographical and Social Cleavages in Germany, DIW Weekly Report 34/2019. 